\title{
PENGARUH PENERAPAN MODEL PEMBELAJARAN ADDIE TERHADAP HASIL BELAJAR SISWA PADA MATA PELAJARAN FIQIH
}

\author{
Risal Qori Amarullah'), Nida Fatmah Wahidah') \\ 1,2 Universitas Islam Negeri Sunan Gunung Djati Bandung \\ 12zhaliezhal85@gmail.com \\ 2Nidafatmahwahidah@gmail.com
}

\begin{abstract}
ABSTRAK
Penelitian ini bertujuan untuk mengetahui pengaruh penerapan model pembelajaran ADDIE pada mata pelajaran Fiqih terhadap hasil belajar siswa kelas VIII Siswa SMPIT Plus Al Ittihad Cianjur tahun ajaran 2020/2021. Metode yang digunakan pada penelitian ini adalah Quasi Eksperimen. Pada populasi penelitian ini yaitu seluruh siswa kelas VIII yang terdiri dari 8 kelas. Sampel pada penelitian ini yaitu kelas VIII A yang berjumlah 30 siswa. Instrumen penelitian berupa soal uraian. Teknik pengumpulan data yang digunakan yaitu tes dan observasi. Teknik analisis data menggunakan SPSS 26.0. Berdasarkan analisis dari hasil hipotesis di atas dapat disimpulkan bahwa nilai sig adalah 0,000. Karena nilai sig <0,05, maka Ho ditolak, H1 diterima sehingga disimpulkan bahwa hasil belajar fiqih dengan model pembelajaran konvensional dan dengan menggunakan model pembelajaran ADDIE berbeda, dengan kata lain pengunaan model pembelajaran ADDIE sangat efektif dalam meningkatkan hasil belajar fiqih siswa. Pelaksanaan penerapan model pembelajaran ADDIE pada mata pelajaran Fiqih dengan tema "Kurban" SMPIT Plus Al Ittihad Cianjur dengan menerapkan langkah-langkah pembelajaran ADDIE yaitu, analisis, desain, pengembangan, implementasi dan evaluasi.
\end{abstract}

Kata Kunci: Pembelajaran, ADDIE, Fiqih.

\begin{abstract}
This study aims to determine the effect of the application of the ADDIE learning model in the Jurisprudence subject to the learning outcomes of class VIII students of SMPIT Plus Al Ittihad Cianjur in the 2020/2021 academic year. The method used in this research is Quasi Experiment. The population of this study was all students of class VIII consisting of 8 classes. The sample in this study is class VIII A, amounting to 30 students. The
\end{abstract}


research instrument was in the form of description questions. The data collection techniques used were tests and observations. The data analysis technique used SPSS 26.0. Based on the analysis of the hypotheses above, it can be concluded that the sig value is 0,000 . Because the sig value $<0.05$, $\mathrm{Ho}$ is rejected, $\mathrm{H} 1$ is accepted, so it can be concluded that there are differences in fiqh learning outcomes with conventional learning models and by using the ADDIE learning model, in other words, the use of the ADDIE learning model is very effective in improving student fiqh learning outcomes. The implementation of the application of the ADDIE learning model in the Jurisprudence subject with the theme "Kurban" at SMPIT Plus Al Ittihad Cianjur by implementing ADDIE learning steps, namely, analysis, design, development, implementation, and evaluation.

Keywords: Learning, ADDIE, Fiqh.

\section{PENDAHULUAN}

Pendidikan merupakan salah satu kebutuhan diri yaitu kebutuhan pedagogis (intelek), karena pendidikanlah yang dapat mengubah diri kita dari hal terkecil hingga suatu hal yang besar dan di dalam prosesnya kita juga akan mengalami perubahan yang signifikan dalam segi kualitas diri. Pernyataan ini sejalan dengan pandangan Oemar Hamalik bahwa pendidikan adalah "suatu proses yang dirancang untuk mempengaruhi siswa agar sedapat mungkin menyesuaikan diri dengan lingkungannya, sehingga menyebabkan perubahannya sendiri, sehingga dapat berfungsi secara dekat dalam kehidupan masyarakat" (Hamalik, 2008)

Dari pernyataan diatas dapat kita pahami bahwa pendidikan Memberikan dampak yang besar bagi siswa, begitu pula dari pendidikan inilah peserta didik dapat beradaptasi dengan sangat baik terhadap lingkungannya, yang nantinya bermanfaat bagi kehidupannya di masyarakat.

Pendidikan merupakan faktor utama untuk membangun sebuah peradaban suatu bangsa. begitu pentingnya pendidikan sehingga tolak ukur kemajuan bangsapun dinilai dari pendidikan. semakin baik kualitas pendidikan yang dimiliki masyarakat/bangsa, maka semakin baiknya sumber daya masyarakat/bangsa tersebut. Oleh karena itu, perlu adanya strategi khusus untuk membangun pendidikan. proses pendidikan diharapkan berjalan dengan optimal sehingga dapat mencapai tujuannya secara optimal pula. Sementara inti dari proses pendidikan itu sendiri adalah proses pembelajaran. (Wiyani, 2013) Dengan ini dapat dikatakan bahwa semakin berkualitas dan semakin efektif proses pembelajaran, maka semakin berkualitas pula pendidikan di bangsa ini. 
Pembelajaran yakni Konsep kegiatan dua dimensi yang harus direncanakan dan dilaksanakan, dan ditujukan untuk menguasai banyak kemampuan dan indikator sebagai gambaran hasil belajar. (Abdul Majid, 2013) Pada hakikatnya pembelajaran merupakan kegiatan yang tersusun untuk menyesuaikan / merangsang kemampuan belajar seseorang sehingga dapat memenuhi tujuan pembelajaran. Oleh karena itu, kegiatan tersebut akan mengarah pada kegiatan dua dimensi. (Abdul Majid, 2013)

Seiring berkembangnya zaman, proses pembelajaran dituntut untuk melakukan pembaharuan-pembaharuan yang cenderung mengejar efesiensi dan efektivitas agar mampu menjadi pembelajaran yang berkualitas. Dengan demikian pembelajaran diharuskan adanya inovasi-inovasi yang mampu berkembang sehingga beriringan dengan perkembangan teknologi. Penerapannya pun harus praktis di mana di dalamnya memiliki unsur-unsur kenyamanan dan kemudahan serta dapat meningkatkan prestasi belajar siswa.

Dalam pendidikan, hasil belajar merupakan yang prestasi Pembelajaran dicapai melalui proses kegiatan belajar mengajar. Hasil belajar dapat tercermin dari nilai yang diperoleh guru dari mata pelajaran yang dipelajari oleh siswanya. Tentunya setiap kegiatan pembelajaran diupayakan memiliki dampak pembelajaran yang paling besar. Ada beberapa faktor yang mempengaruhi proses pencapaiannya, prestasi belajar. (Mulyasa, 2005). Salah satu factor yang mempengaruhinya adalah guru dan metode pembelajaran. Karena suatu metode pembelajaran yang baikakan membantu seorang guru untuk mencapai pembelajaran yang diharapkan serta tercapainya tujuan pembelajaran.

. Metode adalah sarana yang digunakan untuk mengimplementasikan suatu program yang tersusun dalam kegiatan nyata untuk tercapainya tujuan yang diharapkan dengan sebaik-baiknya. (Sanjaya, 2018) Dengan demikian pendidik memiliki tanggung jawab memberikan kesempatan peserta didik dalam mengembangkan kompetensi yang dimilikinya.

Permasalahan yang terjadi di SMPIT Al Ittihad Cianjur adalah penggunaan metode pembelajaran masih menggunakan cara yang konvensional. Untuk pembelajaran Fiqih yang ada di kelas VIII guru cenderung menggunakan metode ceramah. Terlihat disetiap pembelajarannya hanya berpusat kepada guru sehingga siswa menjadi pasif hanya mendengar dan melihat, tidak langsung ikut aktif dalam pembelajaran. Sehingga metode tersebut berpengaruh terhadap hasil belajar siswa. 
50 | Tarbawi : Jurnal Pendidikan Islam Vol. 18. No. I. Januari - Juni 202l

Pelajaran Fiqih adalah Bagian dari tema pendidikan agama Islam, membahas tentang ajaran agama Islam yang sesuai dengan hukum Islam. tentang cara-cara manusia melaksanakan ibadah kepada Allah dan mengatur kehidupan sesama manusia dan alam sekitarnya. (Indonesia, 2014) Menurut Nazar bakri adalah "suatu ilmu yang mempelajari bermacam-macam syariat hukum islam yang mengatur bermacam- macam aturan hidup bagi manusia baik yang bersifat individual maupun yang berbantuk masyarakat sosial. (Bakri, 1996)

Dengan demikian dapat disimpulkan bahwa fiqih adalah suatu ilmu yang membahas tentang hal-hal yang berkenaan dengan syariat hukum Islam yang bersifat praktis tentang cara-cara manusia melaksanakan ibadah kepada Allah dan mengatur kehidupan sesama manusia dan alam sekitarnya yang bersifat individu maupun masyarakat.

Salah satu metode pembelajaran yang dapat dilakukan untuk mengatasi masalah diatas adalah metode ADDIE. Model ADDIE bisa dijadikan acuan dalam mengembangkan perangkat pembelajaran yang efektif dengan beberapa tahapan. Tahapan yang diterapkan dalam model pembalajaran ADDIE ini diharapkan dapat meningkatkan hasil belajar siswa.

\section{METODE PENELITIAN}

Metode yang digunakan adalah Quasi Eksperimen dengan desain penelitian Nonequivalent Experimental Group Design. Menurut Sugiyono (2017) Desain yang digunakan dalam penelitian eksperimen ini ialah desain kelompok pretest-posttest (control group pretestt and posttest design). Dalam desain ini baik kelas kontrol maupun kelas eksperimen harus melakukan pretest dan posttest, hanya saja untuk kelas eksperimen dan kontrol diberikan perlakuan berbeda. Perlakuan kelas control menggunakan model pembelajaran konvensional dan kelas eksperimen menggunakan model pembelajaran ADDIE.

Penelitian ini dilaksanakan di SMP Plus Al Ittihad Cianjur yang beralamat di JI.Raya Bandung No.3 Bojong Karangtengah Kabupaten Cianjur Jawa Barat

Penilaiannya terdiri dari instrumen tes. Instrument tes menggunakan soal bentuk uraian. Penilaian ini dilakukan untuk mengukur sejauh mana perbedaan hasil belajar peserta didik dengan menggunakan model pembelajaran konvensional dan model pembelajaran ADDIE. 
Populasi adalah kumpulan wilayah dari objek dengan kualitas dan karakteristik tertentu, peneliti memilih untuk mempelajarinya dan kemudian membuat kesimpulan. (Sugiyono, Metode Penelitian Kuantitatif dan Kualitatif, 2011). Maka populasi adalah data keseluruhan yang diperhatikan oleh peneliti, sedangkan sampel adalah sebagian dari populasi. (Sugiyono, 2011), Sampel yang diambil dalam penelitian bersifat mewakili. Pada populasi penelitian ini yaitu seluruh siswa kelas VIII yang terdiri dari 8 kelas peneliti melakukan eksperimen di kelas VIII A yang berjumlah 30 siswa.

Dalam penelitian ini, pengolahan data yang digunakan terdiri dari tiga tahapan, pertama mengumpulkan hasil data kuantitatif, yaitu tes hasil belajar dengan menggunakan model pembelajaran konvensional, Kedua, mengumpulkan data kuantitatif hasil belajar dengan menggunakan model pembelajaran ADDIE, Ketiga, membuat tafsiran dan kesimpulan hasil penelitian dari data kuantitatif, yaitu mengenai sejauh mana tingkat keberhasilan pembelajaran dengan menggunakan model pembelajaran ADDIE terhadap hasil belajar fiqih peserta didik.

Setelah diperoleh data pretest dan posttest, maka selanjutnya dilakukan analisis data. Teknik analisis data menggunakan SPSS 26.0. Langkah-langkah analisis data dalam penelitian ini, yaitu uji normalitas, uji hipotesis dengan menggunakan paired sampel test.

\section{PEMBAHASAN}

\section{Pengertian Model Pembelajaran ADDIE}

ADDIE merupakan akronim untuk Analyze, Design, Develop, Implement dan Evaluate. ADDIE adalah sebuah konsep pengembangan produk, maksudnya sebuah konsep yang diterapkan untuk membangun performa dasar pembelajaran. Model pembelajaran ADDIE merupakan model pembelajaran berorientasi sistem yang mencakup semua komponen pembelajaran. Hakikatnya pada metode sistem yang efektif dan proses yang interaktif, yaitu hasil evaluasi setiap tahap dapat membawa pengembangan dalam pembelajaran ke tahap selanjutnya. (Junaedi, 2020).

Konsep model ADDIE ini berawal dari model desain pembelajaran serta teori belajar yang digunakan angatan darat AS tahun 1950. Pada tahun 1975 Model ini di kembangkan di Florida State University oleh bidan teknologi untuk digunakan oleh semua militer AS. Selain itu, pada tahun 1980-an para ahli pendidikan melakukan revisi sehingga muncul model yang lebih dinamis dari sebelumnya. Model tersebut akhirnya dapat digunakan di segala bidang salah satu nya di bidang strategi dan 
52 | Tarbawi : Jurnal Pendidikan Islam Vol. 18. No. I. Januari - Juni 202I

metode pembelajaran (admin Anda, 2016). Model ADDIE dapat digunakan sebagai referensi dalam mengembangkan perangkat pembelajaran yang efisien dalam berbagai tahap. (Fajriyah, 2019)

Reiser dan Molenda adalah dua orang ahli yang membantu mengembangkan konsep ADDIE, keduanya berbeda dalam membentuk ADDIE secara visual. Reiser mengekspresikan ADDIE dengan menggunakan kata kerja (menganalisis, merancang, mengembangkan, menerapkan, mengevaluasi). Reiser menjelaskan dengan jelas revisi atau perbaikan yang terjadi di setiap perubahan. Molenda menunjukkan bahwa semua komponen memiliki kata benda (analisis, desain, pengembangan, implementasi, evaluasi).. Model pengembangan ADDIE yaitu model berbasis metode sistem yang efektif dan proses yang interaktif, artinya hasil evaluasi dari setiap tahapan dapat membawa pengembangan pembelajaran ke tahap selanjutnya.

\section{Langkah-Langkah Model ADDIE}

Secara umum tahapan dalam model ADDIE ini terdapat lima langkah, yakni Analyze, Design, Develop, Implement dan Evaluate, yang akan dijelaskan satu persatu

\section{a. Analyze (Analisis)}

Tahap pertama pengembangan konten adalah analisis. Analisis mengacu pada pengumpulan informasi tentang peserta pelatihan, seperti bagaimana peserta pelatihan memandang konten, tugas yang dituntaskan, dan apa tujuan dari keseluruhan proyek. Kemudian, tugas desainer instruksional adalah mengklasifikasikan informasi agar isinya lebih aplikatif. Pertanyaan-pertanyaan yang muncul pada desainer pembelajaran yang mencari informasi tentang siswa adalah: 1) Apa tujuan pembuatan materi baru berbasis teknologi informasi, 2) Apa tujuan yang ingin diraih, 3) Berapa banyak pengetahuan yang diketahui Trinee? Materi apa yang akan disampaikan ; 4) Personil yang menggunakan bahan ajar berbasis teknologi informasi sesuai dengan karakteristiknya; 5) Cara penyampaian materi; 6) Berapa lama batas waktu pengerjaannya. Hasil akhir ini adalah untuk mengetahui kondisi awal dan informasi mengenai peancaan apa yang akan dibuat (Wiyani, 2013)

\section{b. Design (Desain)}


Tahap desain merupakan tahapan kedua dari model ADDIE. Desain pada tahap ini di dapatkan seluruh informasi dari tahap analisis dan memulai proses kreatifitas dari merancang bahan ajar berbasis teknologi informasi aga rtercapainya tujuan pembelajaran. Selain itu pendidik juga mengidentifikasi materi yang akan dbutuhkan, merancang pembelajaran serta menentukan bagaimana cara untuk mengukur prestasi belajar trainee. Hasil akhir pada tahap ini adalah story board atau blueprint (sebuah cetak biru) pembelajaran berbasis teknologi informasi. (Isya', 2017)

\section{c. Develompment (Pengembangan)}

Tahap ketiga ialah pengembangan,Pada tahap pengembangan ini materi pembelajaran di rancang dengan (storyboard) yang telah dibuat pada tahap sebelumnya yaitu tahap desain. Alat yang diperlukan foto, gambar, audio, grafis, vidio dan multimedia yang lain dalam bahan ajar. Pada tahap ketiga inilah yang dilakukan uji coba materi ajar yang telah dibuat pada beberapa trainee untuk memperoleh feedback dari mereka.

\section{d. Implementation (Pelaksanaan)}

Kita sudah memasuki tahap keempat yakni pelaksanaan (implementation). Pada bagin ini, kegiatan pemelajaran dilaksanakan di kelas, peserta didik diberi pengetahuan, penampilan mereka dinilai, dan diidentfikasi cara-cara mereka untuk meningkatkan hasil belajar. Tahap Pengembangan ini, peserta didik diarahkan bagaimana menggunakan teknologi yang digunakan. sebelum mengarahkan peserta didik, pastikan terlebih dahulu teknologi yang digunakan harus berjalan sebagaiana mestinya.

Pada bagian ini, merupakan evaluasi dari tahap perencanaan (design). Pendidik perlu menulis yang menjadi faktor penghambat dan pendukung dalam meningkatkan pembelajaran trainee dari materi ajar yang telah dikemas. Hasil akhirnya yaitu adanya pembelajaran berbasis TIK yang efektif dan efisien baik didalam atau diluar kelas.

\section{e. Evaluation (Evaluasi)}

Tahap evaluasi adalah tahap terakhir dalam model ADDIE. Pada bagian evaluasi, setelah kegiatan dalam pembelajaran itu direfleksikan dan direvisi, mulai dari tahap analisis, desain, pengembangan, pelaksanaan. Apabila ditemukan sesuatu yang diperlukan ditingkatkan, diidentifikasi dan disempurnakan. Seperti kita ketahui bahwa evaluasi mempunya dua macam, begitupula pada evaluasi model ADDIE ini. Terdapat dua macam evaluasi yaitu Evaluasi Formatif dan Sumatif. Evaluasi formatif 
54 | Tarbawi : Jurnal Pendidikan Islam Vol. 18. No. I. Januari - Juni 202l

ialah penilaian yang di lakukan pada tahap masing masing. Adapun evaluasi sumatif adalah untuk mengukur kemampuan belajar trainee dari perangkat bahan ajar berbasis TIK serta mendapatkan feedback dari trainee. Hasil akhir dari tahapan ini adalah laporan evaluasi dan revisi tiap tahapan sebagai acuan untuk revisi tiap tahapan, serta masukan keseluruhan yang didapat dari buku teks tertulis.

\section{Implementasi Model Pembelajaran ADDIE Pada Pembelajaran Fiqih di SMPIT}

\section{Plus Al Ittihad Cianjur.}

Berikut adalah implementasi pelaksanaan penerapan model pembelajaran ADDIE pada mata pelajaran Fiqih dengan tema "Kurban" di SMPIT Plus Al Ittihad Cianjur.

\section{Analisis}

Dalam tahap ini aspek yang perlu di analisa adalah kognitif dan psikomotorik awal peserta didik, gaya belajar, motivasi, bakat dan minat serta latar belakang pendidikan peserta didik. Oleh karena itu selaku desainer program pembelajaran, kami melakukan beberapa hal sebagai berikut:

a. Dialog dengan peserta didik terkait asal-usul, cita-cita, latar belakang pendidikan dan harapan yang ingin dicapai setelah menyelesaikan program pembelajaran.

b. Menyiapkan beberapa soal pre-test untuk mengukur pengetahuan dan keterampilan yang telah dimiliki peserta didik. Pre-test ini bisa dilakuakan baik secara lisan maupun tertulis. Misalnya terkait materi kurban, guru memberikan ilustrasi kepada siswa tentang bab tersebut bisa seperti gambar hewan-hewan yang dapat dikurbankan (kambing, sapi, domba, kerbau dan unta).

Dari analisis tersebut dapat diperoleh data yang berpengaruh terhadap analisis pembelajaran. Sehingga dapat ditentukan kompetensi apa yang harus dimiliki oleh peserta didik, yaitu:
1) Mengetahui pengertian kurban
2) Mengetahui hukum dan syarat berkurban
3) Mengetahui ketentuan serta hikmah kurban

\section{Desain}


Desain ini mencakup tiga hal yakni: bahan ajar, indikator, metode pembelajaran, dan media pembelajaran secara umum. Bahan ajar yang disampaikan adalah tentang pengertian kurban, jenis-jenis hewan kurban, ketentuan serta hikmah kurbanl. Sedangkan, Indikator mencakup tentang kognitif dan psikomotor apa saja yang harus dimiliki peserta didik setelah menyelesaikan pembelajaran. Dari analisis yang sudah dilakukan dapat ditentukan indikator sebagai berikut:

1) Peserta didik dapat menjelaskan pengertian kurban

2) Peserta didik dapat mengetahui hukum dan syarat berkurban

3) Peserta didik dapat mengetahui ketentuan dan hikmah kurban

Metode yang digunakan dapat berupa ceramah, tanya jawab, demonstrasi, presentasi, dan praktek. Media yang digunakan dapat berupa LKPD (lembar kerja peserta didik), proyektor, power point atau video.

\section{Pengembangan}

Pada tahap ini bahan ajar yang dibutuhkan adalah sebagai berikut:

Tabel 1.

Materi Ajar Mapel Fiqih kelas VIII

\begin{tabular}{|c|c|c|c|c|}
\hline No & Materi Pembelajaran & Metode & Media & \\
\hline 01 & $\begin{array}{l}\text { A. Pengertian Kurban } \\
\text { Secara bahasa berasal dari } \\
\text { Bahasa Arab Qaraba yang artinya } \\
\text { "dekat". Sedangkan secara istilah } \\
\text { agama kurban adalah beribadah } \\
\text { kepada Allah Swt. dengan cara } \\
\text { menyembelih hewan tertentu pada } \\
\text { hari raya haji dan hari-hari Tasyrik } \\
\text { tanggal 11,12, dan } 13 \text { Dzulhijjah } \\
\text { yang diniatkan semata-mata untuk } \\
\text { mendekatkan diri kepada Allah } \\
\text { Swt. }\end{array}$ & $\begin{array}{l}\text { Ceramah dan } \\
\text { presentasi }\end{array}$ & $\begin{array}{l}\text { Modul, } \\
\text { Proyektor, } \\
\text { dan PPT }\end{array}$ & LCD \\
\hline 02 & $\begin{array}{l}\text { B. Hukum dan Syarat Berkurban } \\
\text { Melaksanakan kurban hukumnya } \\
\text { sunnah mu'akkad atau sunnah } \\
\text { yang sangat dianjurkan dan }\end{array}$ & $\begin{array}{l}\text { Diskusi dan } \\
\text { Tanya jawab }\end{array}$ & $\begin{array}{l}\text { Proyektor } \\
\text { LCD }\end{array}$ & dan \\
\hline
\end{tabular}


56 | Tarbawi : Jurnal Pendidikan Islam Vol. 18. No. I. Januari - Juni 202l

mendekati wajib bagi mereka yang

memenuhi syarat-syarat sebagai

berikut :

a. Islam

b. Baligh dan Berakal

c. Merdeka (Bukan Hamba Sahaya)

Mampu untuk Berkurban

03

C. Dalil Kurban

Ceramah

PPT dan Modul

Allah Swt. berfirman:

Artinya:

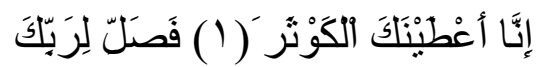

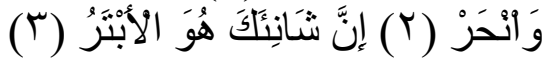

"Sesungguhnya kami telah memberikan kepadamu nikmat yang banyak. Maka dirikanlah shalat karena Tuhanmu dan berkunbanlah. Sesungguhnya orang-orang yang membencimu adalah (dialah) yang terputus. "(QS. Al-Kautsar:1-3). Juga diterangkan dalam Al-Qur'an surat An-Nahl ayat 123:

Artinya:

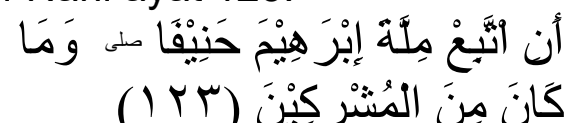

"Ikutilah agama Ibrahim yang lurus, dan dia bukanlah termasuk orang musyrik" (QS. An-Nahl : 123)

\section{Implementasi}

Pada tahap ini, Ada tiga tahap dalam penyampaian bahan ajar atau materi pembelajaran, yakni tahap awal atau pendahuluan, tahap inti, dan tahap akhir pembelajaran. Ketiga tahap tersebut dilakukan dalam waktu $2 \times 40$ menit. Lebih detailnya:

\section{Tabel 1.}

\section{Kegiatan Pembelajaran Mapel Fiqih kelas VIII}

Jenis Kegiatan Nilai Karakter


Tahap Awal (10 menit)

1. Peserta didik merespon salam tanda mensykuri anugerah Allah dan pertanyaan dari guru yang berhubungan dengan pembelajaran sebelumnya.

2. Peserta didik mendapat informasi tentang hubungan antara pembelajaran sebelumnya dengan pembelajaran yang akan dilaksanakan.

3. Peserta didik Menerima informasi tentang kemampuan, materi, manfaat dan langkah pembelajaran yang akan dilaksanakan.

4. Peserta didik menerima informasi tentang hal-hal yang akan dipelajari dan dikuasai khususnya tentang pembelajaran kurban.

Tahap Inti (60 menit)

1. Peserta didik membaca sebentar dan mengamati materi tentang pengertian kurban

2. Peserta didik mengamati gambar atau video tentang pengertian kurban.

3. Peserta didik menerima pertanyaan yang diberikan oleh guru seputar materi

4. Peserta didik mencari jawaban pertanyaan pada yang diberi oleh guru dengan membaca buku ajar dan buku referensi lain

5. Peserta didik mengumpulkan informasi yang dilakukannya dan melengkapinya dengan membaca buku ajar dan buku referensi terkait pengertian kurbanhukum dan syarat kurban, dalil kurban.

6. Peserta didik berdiskusi dalam kelompok untuk mengidentifikasi dan menganalisis berbagai informasi yang diperoleh, kemudian menggunakannya sebagai bahan merangkum materi tentang kurban

7. Peserta didik menyusun hasil diskusi tentang binatang halal.

Tahap Akhir (10 menit)

1. Mengevaluasi seluruh rangkaian aktivitas

pembelajaran dan hasil-hasil yang diperoleh untuk selanjutnya secara bersama menemukan manfaat langsung mauun tidak langsung dari hasil pembelajaran yang berlangsung

2. Peserta didik saling memberikan umpan balik/refleksi hasil pembelajaran yang telah dicapai.
Santun, peduli, toleransi dan jujur.

Jujur, disiplin, tanggungjawab, peduli, gotong royong, percaya diri.
Santun, peduli, toleransi, jujur 
58 | Tarbawi : Jurnal Pendidikan Islam Vol. I8. No. I. Januari - Juni 202l

3. Menginformasikan rencana kegiatan pembelajaran untuk pertemuan berikutnya

4. Menutup kegiatan pembelajaran dengan bersamasama

\section{Evaluasi}

\section{1) Evaluasi Formatif}

Berikut adalah beberapa contoh penilaian formatif dalam materi di atas:

a. Apa pengertian kurban?

b. Berikan contoh jenis-jenis hewan kurban?

c. Coba sebutkan hikmah melaksanakan kurban?

Selain evaluasi formatif berupa pertanyaan seperti diatas, yang dapat disampaikan secara lisan maupun tulisan, penilaian sikap juga dapat dilakukan dengan beberapa kriteria sebagai berikut:

a. Apakah siswa menyukai rencana pembelajaran yang telah mereka ikuti sejauh ini?

b. Apa keuntungan siswa mengikuti program pembelajaran ini?

c. Seberapa jauh siswa dapat mempelajari materi atau konten pembelajaran?

d. Sejauh mana siswa dapat menerapkan pengetahuan, sikap, dan keterampilan yang mereka telah pelajari?

e. Seberapa besar kontribusi rencana studi yang diterapkan terhadap hasil belajar siswa?

\section{2) Evaluasi Sumatif}

Evaluasi sumatif dapat berupa soal pilihan ganda, isian pendek, maupun soal essay. Berikut adalah beberapa contoh penilaian sumatif:

1. kurban yaitu...

2. Berikan contoh hewan kurban minimal 3....

3. Sebutkan ketentuan dan himha kurban. . .

Berdasarkan wawancara yang dilakukan peneliti pada tanggal 10 Februari 2021 dengan Ibu Diny Wahdaniat selaku guru mata pelajaran Fiqih, bahwa mata pelajaran Fiqih dikelas VIII sebelum menggunakan model pembelajaran ADDIE cenderung nilai prestasi didik tidak meningkat. Maka lbu Diny Wahdaniat sangat tertarik ketika peneliti Ingin menerapkan model ADDIE dalam pemmbelajaran Fiqih, karena sebelumnya lbu Diny Wahdaniat belum pernah menerapkan model 
pembelajaran tersebut. Jumlah peserta didik di kelas VIII SMPIT Plus al Ittihad Cianjur sebanyak 30. Berikut ini merupakan hasil data statistik deskriptif metode pembelajaran ADDIE dan hasilbelajar Fiqih.

4. Tingkat Keberhasilan Model pembelajaran ADDIE dalam Pembelajaran Fiqih Untuk meningkatkan Hasil Belajar Siswa

a. Uji Normalitas Data

Tabel 3. Case Processing Summary Hasil Belajar Fiqih Menggunakan Model Pembelajaran Konvensional dan ADDIE Case Processing Summary

\begin{tabular}{|c|c|c|c|c|c|c|}
\hline & \multicolumn{6}{|c|}{ Cases } \\
\hline & \multicolumn{2}{|c|}{ Valid } & \multicolumn{2}{|c|}{ Missing } & \multicolumn{2}{|c|}{ Total } \\
\hline & $\mathrm{N}$ & Percent & $\mathrm{N}$ & Percent & $\mathrm{N}$ & Percent \\
\hline $\begin{array}{l}\text { Model_Pembelajaran_Konve } \\
\text { nsional }\end{array}$ & 30 & $100,0 \%$ & 0 & $0,0 \%$ & 30 & $100,0 \%$ \\
\hline Model_Pembelajaran_ADDI & 30 & $100,0 \%$ & 0 & $0,0 \%$ & 30 & $100,0 \%$ \\
\hline$E$ & & & & & & \\
\hline
\end{tabular}

Tabel 1. adalah tabel output dari analisis statistik secara inferensial dua sampel berhubungan / berpasangan (Paired Sample Test) melalui SPSS versi 26 IBM. Jumlah data valid (jumlah data siswa) yang diolah sebanyak 30 siswa dan Missing 0 serta total $100 \%$.

Tabel 4. Normalitas Data Hasil Belajar Fiqih Dengan Menggunakan Model Pembelajaran Konvensional dan ADDIE Tests of Normality

\begin{tabular}{|c|c|c|c|c|c|c|}
\hline & \multicolumn{3}{|c|}{ Kolmogorov-Smirnov a } & \multicolumn{3}{|c|}{ Shapiro-Wilk } \\
\hline & Statistic & df & Sig. & Statistic & df & Sig. \\
\hline $\begin{array}{l}\text { Model_Pembelajaran_Konve } \\
\text { nsional }\end{array}$ & ,155 & 30 & ,065 & ,922 & 30 & ,031 \\
\hline $\begin{array}{l}\text { Model_Pembelajaran_ADDI } \\
\text { E }\end{array}$ & ,192 & 30 & ,006 & ,907 & 30 & ,012 \\
\hline
\end{tabular}

a. Lilliefors Significance Correction

Tabel 2 adalah tabel normalitas data, Hasil analisis output ini menjelasnkan hasil uji apakah sebuah distribusi data dapat dikatakan normal ataukah tidak maka pedoman pengambilan keputusannya adalah:

a. Jika nilai Sig (signifikansi / nilai probabilitas) lebih kecil dari < 0,05 maka distribusi tidak normal.

b. Jika nilai Sig (signifikansi / nilai probabilitas) lebih besar dari > 0,05 maka distribusi normal. 
60 | Tarbawi : Jurnal Pendidikan Islam Vol. 18. No. I. Januari - Juni 202I

Ada 2 macam uji kenormalan distribusi data yang dapat digunakan yaitu kormogorov-smimov dan shapiro-wilk. Dari tabel di atas terlihat semua nilai sig pada kormogorov-smimov hasil belajar fiqih dengan model konvensional dan hasil belajar fiqih dengan model pembelajaran ADDIE adalah $>0.05$ yaitu hasil belajar fiqih dengan model konvensional signya 0,65 dan hasil belajar fiqih dengan model ADDIE signya 0,06 , demikian pula pada shapiro-wilk semua nilai sig adalah $>0,05$ yaitu hasil belajar fiqih dengan model konvensional signya 0,31 dan hasil belajar fiqih dengan model ADDIE signya 0,12. Kesimpulannya data skor hasil belajar fiqih dengan menggunakan model konvensional dan hasil belajar fiqih dengan menggunakan model ADDIE berdistribusi normal.

Tabel 5. Normal Q-Q Plot Of Hasil Belajar Fiqih Siswa Dengan Model Pembelajaran Konvensional

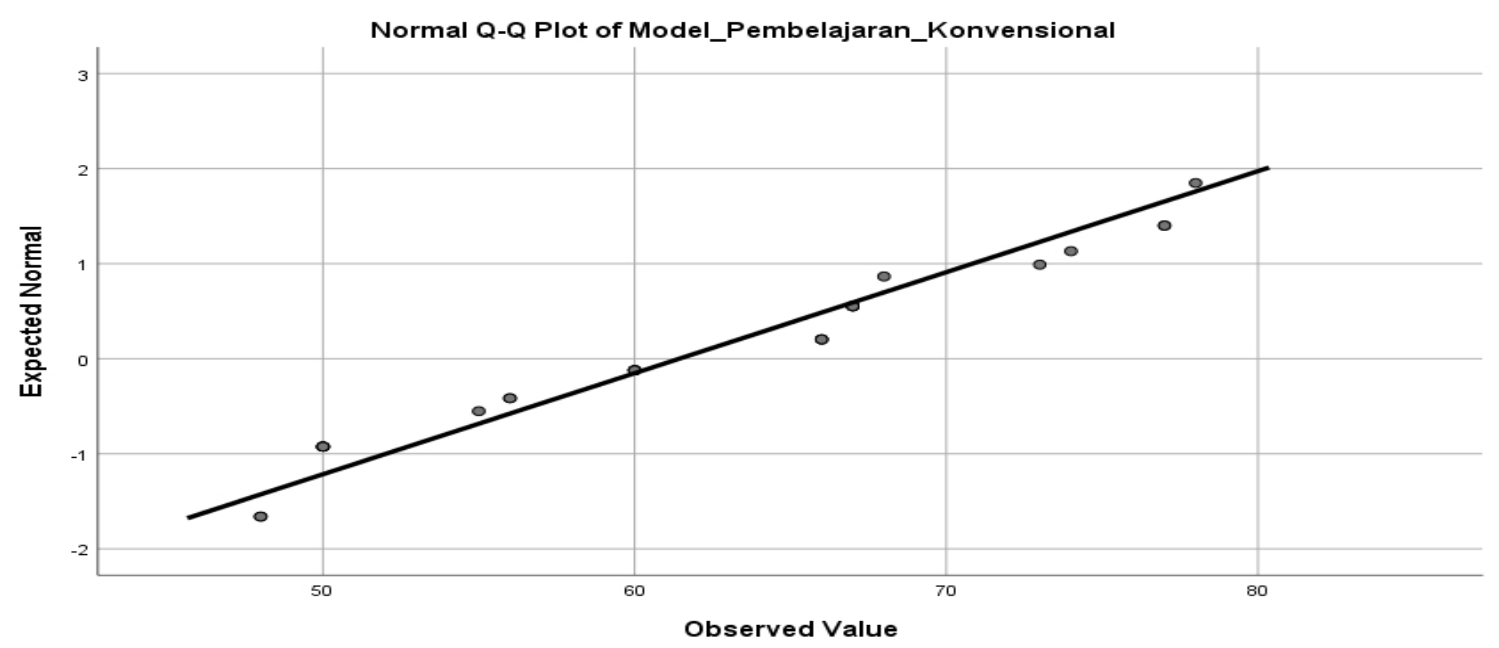

Tabel 6. Normal Q-Q Plot Of Hasil Belajar Fiqih Siswa engan Model Pembelajaran ADDIE 


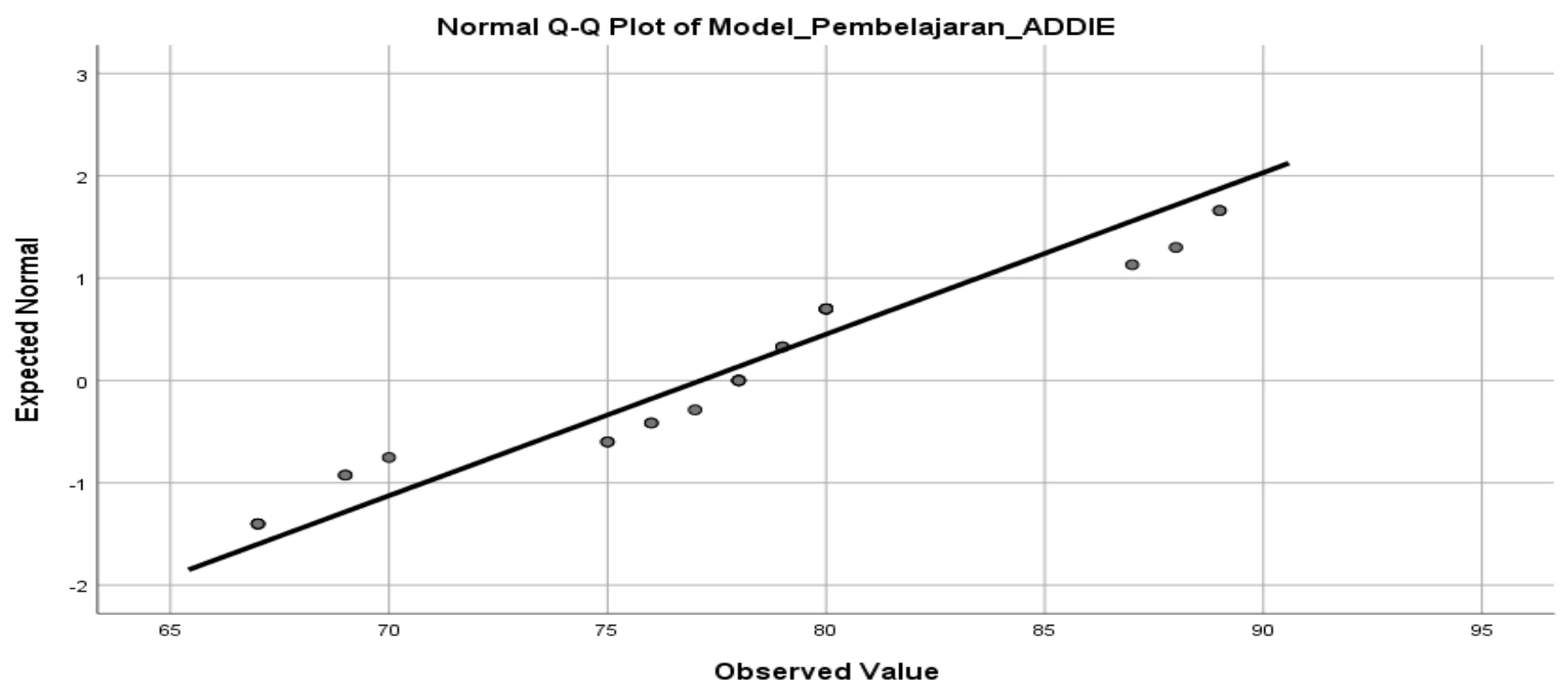

Tabel 7. Paired Samples Statistics Hasil Belajar Fiqih Siswa Menggunakan Model Pembelajaran Konvensional dan ADDIE

\begin{tabular}{|c|c|c|c|c|c|}
\hline \multicolumn{6}{|c|}{ Paired Samples Statistics } \\
\hline & & Mean & $\mathrm{N}$ & Std. Deviation & Std. Error Mean \\
\hline \multirow[t]{2}{*}{ Pair 1} & $\begin{array}{l}\text { Model_Pembelajaran_Konve } \\
\text { nsional }\end{array}$ & 61,4333 & 30 & 9,40903 & 1,71785 \\
\hline & $\begin{array}{l}\text { Model_Pembelajaran_ADDI } \\
\text { E }\end{array}$ & 77,1333 & 30 & 6,33400 & 1,15642 \\
\hline
\end{tabular}

Pada tabel 5 terlihat ringkasan statistik dari kedua sampel untuk skor hasil belajar fiqih dengan model pembelajaran konvensional dengan model ADDIE. Untuk skor hasil belajar fiqih dengan model pembelajaran konvensional rata-ratanya adalah 61,4333dan skor hasil belajar fiqih dengan model pembelajaran ADDIE adalah 77, 1333

Selanjutnya tampilan output dibawah ini memperlihatkan hubungan/korelasi antara kedua variable tersebut:

Tabel 8. Paired Samples Correlations Hasil Belajar Fiqih Siswa Menggunakan Model Pembelajaran Konvensional dan ADDIE 
62 | Tarbawi : Jurnal Pendidikan Islam Vol. 18. No. I. Januari - Juni 202l

Paired Samples Correlations

\begin{tabular}{ll|r|r|r} 
& & N & Correlation & \multicolumn{1}{c}{ Sig. } \\
\hline Pair 1 & Model_Pembelajaran_Konve & 30 &, 004 &, 516 \\
& nsional \& & & \\
& Model_Pembelajaran_ADDI & & & \\
E & & & \\
\hline
\end{tabular}

Berdasarkan hasil korelasi antara kedua variable menghasilkan nilai sig sebesar 0,516 (Sig >0,05). Hal ini menunjukan bahwa antara kedua variable tersebut tidak terdapat hubungan.

Untuk melihat kuatnya hubungan tersebut dari nilai korelasi yaitu 0,004, kita bandingkan nilai korelasi tersebut dengan rentang di bawah ini:

Tabel 9. Nilai korelasi

\begin{tabular}{cl}
\hline Koefisien & \multicolumn{1}{c}{ Kekuatan Hubungan } \\
0,00 & Tidak ada hubungan \\
\hline $0,01-0,09$ & Hubungan kurang berarti \\
$0,10-0,29$ & Hubungan lemah \\
\hline $0,30-0,49$ & Hubungan moderat \\
\hline $0,50-0,69$ & Hubungan kuat \\
\hline $0,70-0,89$ & Hubungan sangat kuat \\
$>0,90$ & Hubungan mendekati sempurna \\
\hline
\end{tabular}

Nilai 0,004 berada pada rentang $0,01-0.09$ yaitu hubungan yang kurang berarti, hal ini menunjukan bahwa korelasi antara hasil belajar fiqih siswa dengan model pembelajaran konvensional dan dengan model pembelajaran addie adalah sangat lemah dan tidak berhubungan secara berarti/nyata.

\section{Perumusan Hipotesis}

Sedangkan untuk melihat perbedaan skor pretest dan postest sebelum dan sesudah diterapkan MPI dapat dilihat pada gambar dibawah ini:

Tabel 10 Paired Samples Test Hasil Belajar Fiqih Siswa Dengan Menggunakan Model Pembelajaran Konvensional dan ADDIE

\section{Paired Samples Test}




\begin{tabular}{|c|c|c|c|c|c|c|c|c|c|}
\hline & & \multirow[b]{2}{*}{ Mean } & \multirow{2}{*}{$\begin{array}{c}\text { Std. } \\
\text { Deviation }\end{array}$} & \multirow{2}{*}{$\begin{array}{c}\text { Std. Error } \\
\text { Mean }\end{array}$} & \multicolumn{2}{|c|}{$\begin{array}{l}\text { 95\% Confidence } \\
\text { Interval of the } \\
\text { Difference }\end{array}$} & & & \multirow{2}{*}{$\begin{array}{l}\text { Sig. (2- } \\
\text { tailed) }\end{array}$} \\
\hline & & & & & Lower & Upper & & & \\
\hline \multirow[t]{6}{*}{ Pair 1} & Model_Pem & \multirow[t]{6}{*}{$-15,70000$} & \multirow[t]{6}{*}{8,19651} & \multirow[t]{6}{*}{1,49647} & \multirow[t]{6}{*}{$-18,76063$} & \multirow[t]{6}{*}{$-12,63937$} & \multirow[t]{6}{*}{$-10,491$} & \multirow[t]{6}{*}{29} & \multirow[t]{6}{*}{, 000} \\
\hline & belajaran_K & & & & & & & & \\
\hline & onvensional & & & & & & & & \\
\hline & - & & & & & & & & \\
\hline & Model_Pem & & & & & & & & \\
\hline & $\begin{array}{c}\text { belajaran_A } \\
\text { DDIE }\end{array}$ & & & & & & & & \\
\hline
\end{tabular}

\section{Hipotesis:}

Penentuan hipotesis berdasarkan:

Jika nilai sig $>0,05$ maka Ho diterima

Jika nilai sig $<0,05$ maka Ho ditolak

Keputusan:

Berdasarkan tampilan Tabel 7 output paired sample test terlihat bahwa nilai sig adalah 0,000 . Karena nilai sig $<0,05$, maka Ho ditolak, H1 diterima sehingga disimpulkan bahwa terdapat perbedaan hasil belajar fiqih dengan model pembelajaran konvensional dan hasil belajar fiqih dengan model pembelajaran ADDIE, dengan kata lain pengunaan model pembelajaran ADDIE sangat efektif dalam meningkatkan hasil belajar fiqih siswa.

\section{Tabel 11. Descriptive Statistics Hasil Belajar Fiqih Siswa Dengan Menggunakan Model Pembelajaran Konvensional dan ADDIE}

\section{Descriptive Statistics}

\begin{tabular}{lr|r|r|r|r} 
& N & Minimum & Maximum & \multicolumn{1}{c|}{ Mean } & Std. Deviation \\
\hline $\begin{array}{l}\text { Model_Pembelajaran_Konve } \\
\text { nsional }\end{array}$ & 30 & 48,00 & 78,00 & 61,4333 & 9,40903 \\
\hline $\begin{array}{l}\text { Model_Pembelajaran_ADDI } \\
\text { E }\end{array}$ & 30 & 67,00 & 89,00 & 77,1333 & 6,33400 \\
\hline Valid N (listwise) & 30 & & & & \\
\hline
\end{tabular}

Berdasarkan Tabel Descriptive Statistics memperlihatkan bahwa skor-skor hasil belajar fiqih siswa dengan model pembelajaran konvensional adalah :

$>$ Nilai minimum $=48,00$ dan nilai maksimum $=78,00$

$>$ Rata-rata $=61,4333$ 
64 | Tarbawi : Jurnal Pendidikan Islam Vol. 18. No. I. Januari - Juni 202I

Standar deviasi adalah 9,40903

Sedangkan skor-skor hasil belajar fiqih siswa dengan menggunakan model pembelajaran ADDIE adalah:

$>$ Nilai minimum $=67,00$ dan nilai maksimum $=89.00$

$>$ Rata-rata $=77,1333$

$>$ Standar deviasi adalah 6,33400

Tabel 9. Histogram Hasil Belajar Fiqih Dengan Model Pembelajaran

Konvensional

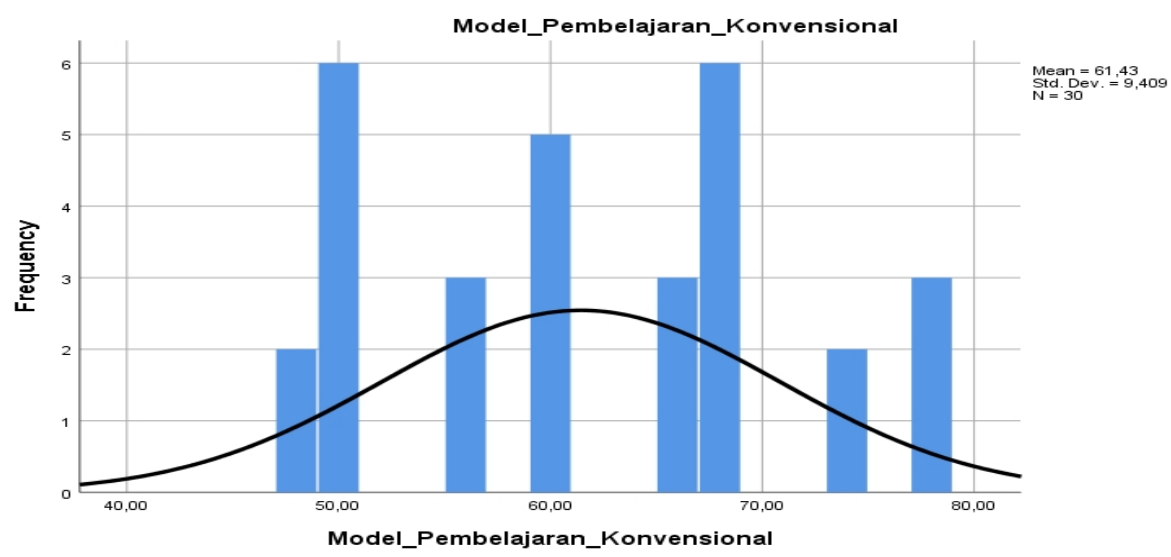

Tabel 10. Histogram Hasil Belajar Fiqih Dengan Model pembelajaran ADDIE

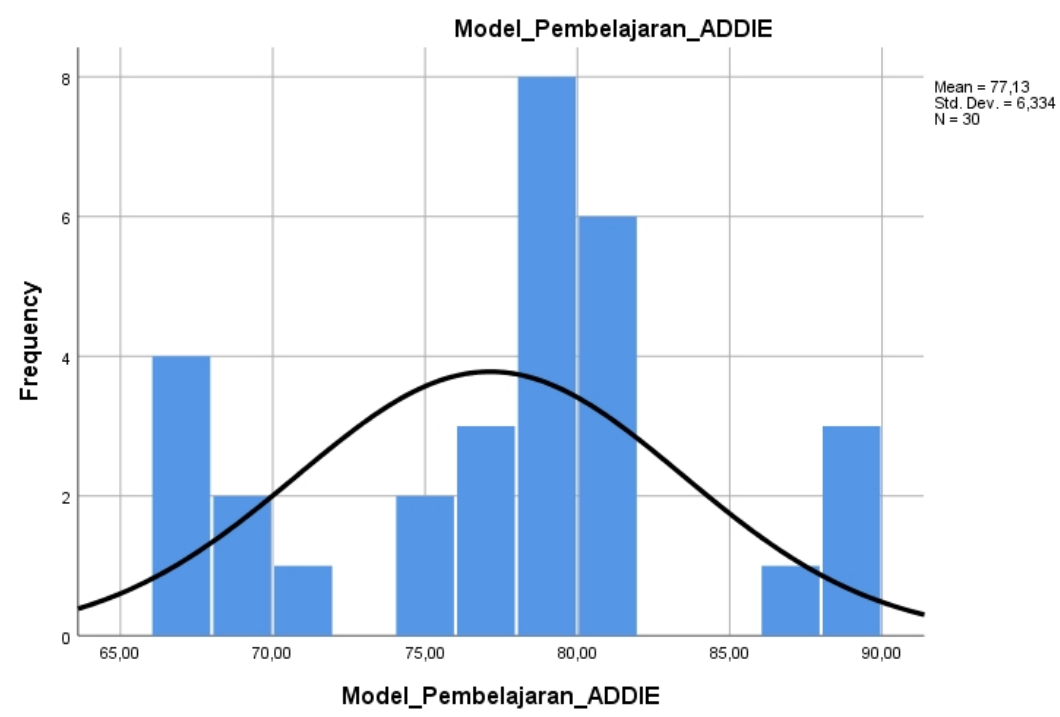

\section{SIMPULAN}

Berdasarkan analisis dari hasil hipotesis di atas dapat disimpulkan bahwa nilai sig adalah 0,000. Karena nilai sig < 0,05, maka Ho ditolak, $\mathrm{H} 1$ diterima sehingga disimpulkan bahwa terdapat perbedaan hasil belajar fiqih dengan model pembelajaran 
konvensional dan dengan model pembelajaran ADDIE, artinya model pembelajaran ADDIE sangat efektif untuk meningkatkan hasil belajar fiqih siswa. Pelaksanaan penerapan model pembelajaran ADDIE pada mata pelajaran Fiqih dengan tema "Kurban" di SMPIT Plus Al Ittihad Cianjur dengan menerapkan langkah-langkah pembelajaran ADDIE yaitu, analisis, desain, pengembangan, implementasi dan evaluasi.

\section{DAFTAR PUSTAKA}

Abdul Majid. (2013). Strategi Pembelajaran. Bandung: PT Remaja Rosdakarya.

Arikunto, S. (2008). Metode praktis prosedur penelitian. Jakarta: Rineka Cipta.

Arikunto, S. (2010). Dasar-dasar Evaluasi Pendidikan. Jakarta: PT Bumi Aksara.

Baharuddin. (2009). Pendidikan dan Psikologi Perkembangan. Yogyakarta: Ar-. Ruzz Media.

Bakri, N. (1996). Fiqih dan Ushul Fiqih . Jakarta: Grafindo Persada.

Basyar, M. K. (2020). Pengembangan Pembelajaran PAI Model ADDIE di SMP Insan Cendikia Mandiri Boarding School Sidoarjo. JURNAL PENDIDIKAN ISLAM Volume 11, Nomor 1, 55.

Cholid Narbuko, d. (2009). Metode Penelitian. Jakarta: Bumi Askara.

Depdiknas. (2003). Undang-undang RI No.20 tahun 2003.tentang sistem pendiidkan nasional.

Fajriyah, N. L. (2019). Pengembangan Instruksional Design Mata Pelajaran Fiqih Kelas VI dengan Model ADDIE di MI Muhammadiyah 5 Surabaya. Jurnal Tarbawi Vol. 16. No. 2, 18.

Hamalik, O. (2008). Kurikulum Dan Pembelajaran . Jakarta:PT Bumi Aksara,Cet. VII. Indonesia, K. a. (2014). Fiqih Pendekatan saintifik 2013 Kelas VII Untuk SMP. Jakarta: Kementrian Agama.

Isya', M. (2017). Menggunakan model Addie untuk mengembangkan model pembelajaran desain pembelajaran untuk materi repetitif berkesan dalam mata pelajaran pendidikan Islam Surah AI Ma'un dan al Fil secara klasikal, kelompok dan individu kelas V SDN Gedongan 2 Kota Mojokerto. TADIBIA J. IIm. Pendidik, 75.

Januri, B. A. (2008). Fiqh Ushul Fiqh. Bandung: Pustaka Setia.

Junaedi, D. (2020, Januari Minggu. DESAIN_PEMBELAJARAN_MODEL_ADDIE 
66 | Tarbawi : Jurnal Pendidikan Islam Vol. 18. No. I. Januari - Juni 202I

K. M. (n.d.). (2014). Panduan Kurikulum Sekolah Islam 2013, meliputi mata pelajaran Pendidikan Agama Islam dan Bahasa Arab. Jakarta: Depag.

Mulyasa, E. (2005). Menjadi Guru Profesional. Bandung: Remaja Rosda Karya.

Rusman. (2013). Model-model Pembelajaran Cet. VI. Jakarta: PT RajaGarafindo Persada.

Sanjaya, W. (2018). Strategi Pembelajaran Berorientasi Standar Proses Pendidikan. Jakarta: Kencana Prenada Media Group.

Sugiyono. (2011). Metode Penelitian Kuantitatif dan Kualitatif. Bandung: Alfabeta.

Sugiyono. (2014). Statistika Untuk Penelitian. Bandung: Alfabeta.

Suryabrata, S. (2002). Psikologi Pendidikan. Jakarta: PT. Grafindo Perkasa. Rajawali.

Tirtonegoro, S. (2001). Anak Super Normal dan Program Pendidikannya. Jakarta: Bina aksara.

Trianto. (2007). Model - Model Pembelajaran Inovatif Berorientasi Konstruktivistik. Jakarta: Prestasi Pustaka.

Wiyani, N. A. (2013). Desain Pembelajaran Pendidikan. Yogyakarta: Ar-Ruzz Media. 